\title{
THE STRANGE DEATH OF THE REALM OF NEW ZEALAND: THE IMPLICATIONS OF A NEW ZEALAND REPUBLIC FOR THE COOK ISLANDS AND NIUE
}

\author{
Andrew Townend*
}

The Cook Islands and Niue are self-governing States within the Realm of New Zealand, freely associated with New Zealand and linked by a shared Head of State: the Sovereign in right of New Zealand. If New Zealand were to become a republic, it is likely that the constitutional link would be broken. The other aspects of the relationships of free association would not necessarily be affected, though their entrenched status in Cook Islands and Niue law could render difficult the technical amendments required to accommodate a republican New Zealand. A Realm of New Zealand of which New Zealand was no longer a part could also live on, with only minor amendment to the laws of the Cook Islands and Niue. But it would be neither desirable nor appropriate for current constitutional arrangements to continue. New Zealand's becoming a republic would ultimately provoke fundamental constitutional change in the Cook Islands and Niue, mostly likely resulting in their becoming self-governing realms or republics in free association with New Zealand.

\section{INTRODUCTION}

During a speech at the London School of Economics in February 2002, the Prime Minister, the Rt Hon Helen Clark, suggested that: ${ }^{1}$

* This paper was submitted in fulfilment of the LLB(Hons) requirements at Victoria University in 2002. The author wishes to thank Dame Silvia Cartwright, Hima Takelesi, and Audrey Brown-Pereira for having been such willing and open interviewees; Alison Quentin-Baxter, Rebecca Kitteridge, Tony Angelo, Matthew Palmer, and Alex Frame for their generous advice and encouragement; and staff at Government House, the Cabinet Office, and the office of Keith Locke MP for making available material referred to in this paper.

1 Francesca Mold "PM Catches Flak Over 'Absurd' Tag for Queen" (25 February 2002) New Zealand Herald Auckland A3. 
[i]t is inevitable that New Zealand will become a republic. It is just a matter of when the New Zealand people are bothered enough to talk about it — it could be 10 years or it could be 20 years, but it will happen.

It seems highly likely that at some point in the future New Zealand will replace its current Head of State, the Sovereign in right of New Zealand, with a president of some sort. This paper proceeds on the assumption that the Prime Minister's view is correct, and that sooner or later New Zealand will become a republic.

The republican debate in this country has until now overlooked the fact that New Zealand is only one element of an eponymous Realm (described in this paper as 'the Realm of New Zealand' or 'the Realm'). The Realm of New Zealand comprises metropolitan New Zealand ('New Zealand'), its two dependent territories, Tokelau and the Ross Dependency, and the self-governing States of the Cook Islands and Niue. Commentators on the republican question have tended to concentrate on the legal and other consequences for New Zealand alone. ${ }^{2}$ This is understandable given that it is New Zealand alone that is contemplating becoming a republic. But the prospect of change to New Zealand's macroconstitutional arrangements (by which is meant the law relating to its Head of State) begs the question of what implications that change might have for the other elements of the Realm. This paper seeks to fill the gap in the republican debate in respect of the Cook Islands and Niue.

While there is a gap in the republican debate, the debate is not a heated one. Ngai Tahu leader Sir Tipene O'Regan has suggested that New Zealand's current constitutional concerns lie, or at least ought to lie, elsewhere: ${ }^{3}$

The primary question for New Zealand is the development of a proper written constitution with a proper developed judicial system and supreme court. When we have those, then I'll worry about the teko teko you put on top of the meeting house.

2 See for example FM (Jock) Brookfield "Republican New Zealand: Legal Aspects and Consequences" [1995] NZ Law Rev 310; Rt Hon Sir Robin Cooke "The Suggested Revolution Against the Crown" in Philip A Joseph (ed) Essays on the Constitution (Brookers, Wellington, 1995) 28; Philip A Joseph Constitutional and Administrative Law in New Zealand (2 ed, Brookers, Wellington, 2001) 558-560; Andrew Ladley "Who should be Head of State?" in Colin James (ed) Building the Constitution (Institute of Policy Studies, Wellington, 2000) 267; Geoffrey Palmer and Matthew Palmer Bridled Power: New Zealand Government Under MMP (3 ed, Oxford University Press, Auckland, 1997) 48-51; Republican Movement of Aotearoa New Zealand Becoming Citizens, Not Subjects <http://www.republic.org.nz/documents/ccpaper.pdf> (last accessed 3 March 2003); Andrew P Stockley "Becoming a Republic? Issues of Law" in Luke Trainor (ed) Republicanism in New Zealand (Dunmore Press, Palmerston North, 1996) 81; Alan Whelan and Barrie Cook New Zealand Republic (Niu Pacific, Wellington, 1997).

3 "Clark Says Republic Here Inevitable" (7 February 2002) New Zealand Herald Online $<$ http://www.nzherald.co.nz/storydisplay.cfm?thesection=news\&thesubsection=\&storyID $=115835>\quad$ (last accessed 3 March 2003). 
Other commentators have perceived only lukewarm public enthusiasm for a New Zealand republic. Professor FM (Jock) Brookfield suggested in 1995 that any change to the status quo was unlikely within the lifetime of the present Queen. ${ }^{4}$ More recently, in a paper presented to the "Building the Constitution" conference in April 2000, Dr Andrew Ladley described the "bonfire of republicanism" as "hard to light, since New Zealand may effectively have its republican cake, and be eating it too". 5 The view that New Zealand is a de facto republic is shared by the Prime Minister, who observed in March 2002 that "[w]e have, to all intents and purposes, the nominal Head of State in our Governor-General". 6

There does seem, however, to be an emerging consensus that while change to a republic may not come for some years, it is inevitable. In 1999, the Third New Zealand Study of Values asked 1201 New Zealand electors whether they were in favour of declaring New Zealand a republic and no longer having 'the Queen of England' as Head of State. ${ }^{7} 32$ per cent of the respondents were in favour of becoming a republic, 39 per cent against, and 24 per cent neither in favour nor against. In 1989 , with a sample size of 1000 , the same question had yielded responses of 16 per cent in favour, 61 per cent against, and 21 per cent neither for nor against.

It is unfortunate that the question was phrased in the way it was. As a matter of constitutional law, 'the Queen of England' does not exist. There is a Queen in right of the United Kingdom of Great Britain and Northern Ireland, but she has nothing to do with New Zealand; New Zealand's Head of State is the Queen in right of New Zealand. ${ }^{8}$ Same person, different hats (as will be explained in more detail below). Nevertheless, in spite of the misleading question, the authors' conclusion on the republican issue is probably correct: ${ }^{9}$

New Zealand is not yet ready to cut its formal ties with the Queen, but that is most definitely the direction [in which] the thinking of the population is heading.

It is certainly the direction in which the Prime Minister's thinking is heading. At the launch of the Crime and Justice Research Centre at Victoria University of Wellington in August 2002, the Governor-General, Dame Silvia Cartwright, questioned the effectiveness of long prison sentences, a

$4 \quad$ FM (Jock) Brookfield "Republican New Zealand: Legal Aspects and Consequences" [1995] NZ Law Rev $310,325-6$.

5 Andrew Ladley "Who should be Head of State?" in Colin James (ed) Building the Constitution (Institute of Policy Studies, Wellington, 2000) 267, 268.

6 "Clark Talks Up Republic" (4 March 2002) New Zealand Herald Auckland A5. See also Brookfield, above, 310 .

7 Paul Perry and Alan Webster New Zealand Politics at the Turn of the Millennium - the Political Report of the Third New Zealand Study of Values (Alpha Publications, Auckland, 1999) 5, 76

8 Constitution Act 1986 (NZ), s 2.

9 Perry and Webster, above, 76 
campaign platform of opposition parties in the 2002 general election. ${ }^{10}$ Some Members of Parliament suggested that Her Excellency's comments had breached the principle that the Sovereign's representative, like the Sovereign herself, remains non-partisan. ${ }^{11}$ This was hardly a novel criticism - Governors-General have on various occasions been accused of sailing too close to the political wind. But the Prime Minister defended Dame Silvia, suggesting that the role of Governor-General might now extend to making a "reasoned contribution to public discourse" while remaining non-partisan in a political sense. ${ }^{12}$ The Prime Minister also took the opportunity to reiterate her own republican views: ${ }^{13}$

One of the challenges for us is we clearly are no longer a dominion of Britain where the Governor-

General is exactly like the Queen. I think we need to consider how the role of governor-general might evolve further. As you know, my view is that one day there will be a president fulfilling the kind of role the governor-general does.

It was with this issue in mind that in 1998 the Cook Islands Political Reform Review Commission suggested that: ${ }^{14}$

it is time to begin thinking about possible changes that may be required if New Zealand becomes a republic. Australia is expected to become a Republic soon and appoint an Australian Head of State. New Zealand may do so not much later. So it is time to consider the advantages and disadvantages of other options if that happens because the Queen is Head of State for the Cook Islands in relation to her "realm" of New Zealand, which includes the Cook Islands, Niue, New Zealand and Tokelau together.

Cook Islanders and Niueans want to know what their options are should New Zealand become a republic. They have been self-governing for the last 37 and 28 years respectively, and it by no means follows that whatever New Zealand does they do too.

The rest of this paper is divided into two broad sections. The first (parts II to IV) is concerned with the Realm of New Zealand as currently constituted. Part II challenges the widely-held view that New Zealand is a realm. It shows that the adoption by the Cook Islands and Niue of selfgovernment in free association with New Zealand, and their retention of the Queen in right of New Zealand as Head of State, instead sparked the development of a Realm of New Zealand of which New Zealand is only one constituent element. The terms of the relationships of free association between New Zealand and the Cook Islands and New Zealand and Niue are set out in part III. Part

10 Nick Venter "Dame Silvia Seen as Reshaping Role" (15 August 2002) Dominion Post Wellington A2.

11 Venter, above.

12 Venter, above.

13 "Clark Foresees President Role" (15 August 2002) New Zealand Herald Auckland A5.

14 Report of the Political Reform Review Commission (tabled in the Cook Islands Parliament as paper no 56, 18 November 1998) 49-50. 
IV examines several aspects of the Realm as it works in practice, including the appointment and nationality of the Governor-General, the role of the Executive Council, and the channelling of advice to the Queen and the Governor-General via the New Zealand Prime Minister.

The second section (parts V to VIII) considers the future of the Realm should New Zealand secede to become a republic. Part V argues that the president of a republican New Zealand would be Head of State for New Zealand alone, though as part VI will show, the severing of the constitutional link would not necessarily bring to an end the relationships of free association. Part VII shows that with only minor amendment a Realm of New Zealand of which New Zealand was no longer a part could continue to function, but goes on to argue that such an arrangement would be short-lived at best. It would be neither desirable nor appropriate for the Cook Islands or Niue to persevere with the status quo. Part VIII concludes by setting out in broad terms four options for the constitutional futures of the Cook Islands and Niue.

\section{NEW ZEALAND AND THE REALM OF NEW ZEALAND}

\section{A $1901-1953$}

1 From dominion to realm; from 'Dominion of New Zealand' to 'New Zealand'

During the first half of the twentieth century New Zealand underwent a transformation in both name and substance. The changes began in 1907, when the Colony of New Zealand was proclaimed the 'Dominion of New Zealand'. ${ }^{15}$ The change in label was inspired by a feeling on the part of the Prime Ministers of the self-governing colonies of the British Empire (New Zealand, Australia, Canada, and South Africa) that a new term was required to distinguish them from the non-selfgoverning colonies. ${ }^{16}$ The title 'Dominion of New Zealand' stuck and was used in official documents until the mid-1940s. ${ }^{17}$

It had been recognised by the end of the Second World War that New Zealand and the other dominions had acquired a full measure of executive competence. ${ }^{18}$ By adopting the Statute of Westminster of 1931 (which New Zealand did in 1947), they could also gain full power to make laws. ${ }^{19}$ Dominion status thus allowed the dominions to be as independent as they wished to be,

15 Philip A Joseph Constitutional and Administrative Law in New Zealand (2 ed, Brookers, Wellington, 2001) 36-38, 110-111; John L Robson New Zealand: The Development of its Laws and Constitution (2 ed, Stevens, London, 1967) 2-4, 10.

16 See the transcript of the Prime Ministers' debate in Kenneth C Wheare The Constitutional Structure of the Commonwealth (Oxford University Press, London, 1960) 6-10.

17 Alison Quentin-Baxter Review of the Letters Patent 1917 Constituting the Office of Governor-General of New Zealand (report to the Prime Minister's Department, Cabinet Office, Wellington, 1980) 130-131.

18 Robson, above, 16.

19 See the Statute of Westminster Adoption Act 1947 (NZ) and the discussion in Philip A Joseph Constitutional and Administrative Law in New Zealand (2 ed, Brookers, Wellington, 2001) 444-447. 
while retaining a common allegiance to the Crown, expressed through their membership of the Commonwealth $^{20}$ (criteria which, arguably, New Zealand still meets). Despite this, the title 'Dominion' was thought to suggest a "notion of inferiority to the United Kingdom, some historical memory of subordinate status, of adolescence, of the Mother Country's apron strings", ${ }^{21}$ and from 1945 onwards the New Zealand Government quietly dropped it. New Zealand joined the United Nations as 'New Zealand' in 1945, and after January 1946 the title 'Dominion of New Zealand' disappeared from official letterheads and legislative drafting policy. ${ }^{22}$

What had New Zealand become, if it was no longer to be described as a dominion? The Queen's Accession Proclamation of 11 February 1952 indicated that dominion status had been replaced by realmhood: 23

[T]he High and Mighty Princess Elizabeth Alexandra Mary is now, by the death of our late Sovereign of happy memory, become Queen Elizabeth the Second, by the grace of God, Queen of this realm and of all her other realms and territories, Head of the Commonwealth, Defender of the Faith ... .

The change from dominion to realm was confirmed in 1953, when Her Majesty proclaimed a separate Royal Title for use in New Zealand: ${ }^{24}$

Elizabeth the Second, by the Grace of God of the United Kingdom, New Zealand and Her Other Realms and Territories Queen, Head of the Commonwealth, Defender of the Faith.

It is widely believed that upon becoming a realm, New Zealand also adopted the title 'Realm of New Zealand'. The leading text on New Zealand constitutional law suggests that: ${ }^{25}$

20 W David McIntyre "The Strange Death of Dominion Status" (1999) 27 Journal of Imperial and Commonwealth History 193, 195. See also the Balfour Declaration of 1926 and related discussion in Kenneth C Wheare The Statute of Westminster and Dominion Status (5 ed, Oxford University Press, London, 1953) 28.

21 Kenneth C Wheare The Constitutional Structure of the Commonwealth (Oxford University Press, London, 1960) 17.

22 McIntyre, above, 5; Alison Quentin-Baxter Review of the Letters Patent 1917 Constituting the Office of Governor-General of New Zealand (report to the Prime Minister's Department, Cabinet Office, Wellington, 1980) 130-131. See for example the Tokelau Act 1948 (NZ), s 3: "Tokelau is hereby declared to be part of New Zealand".

23 Accession Proclamation (1952) I New Zealand Gazette 195. Compare, for example, the Accession Proclamation of George VI, which refers to 'the Dominion of New Zealand' - (1936) III New Zealand Gazette 2435.

24 Royal Titles Act 1953 (NZ), s 2; Royal Titles Proclamation (1953) II New Zealand Gazette 851.

25 Philip A Joseph Constitutional and Administrative Law in New Zealand (2 ed, Brookers, Wellington, 2001) 162. 
New Zealand officially discarded the term ['Dominion'] in 1953, when it adopted the style "Realm of New Zealand".

The New Zealand Official Yearbook states that: ${ }^{26}$

[b]y 1955 it was considered that 'dominion' implied a subordinate role to the United Kingdom, and [the] official style was changed to the 'Realm of New Zealand' which recognised the Queen's position as constitutional head of New Zealand ... without implying a subordinate role to the United Kingdom.

These statements are correct in that New Zealand had indeed discarded the title 'Dominion of New Zealand' by the early 1950s. But they are misleading, because it has never adopted the style 'Realm of New Zealand' (though, as will been seen below, it is now part of a realm of that name). The official title is still, strictly speaking, 'Dominion of New Zealand', since the 1907 proclamation has never been revoked. ${ }^{27}$ But since the late 1940s the preferred name has been simply 'New Zealand'.

\section{Territorial and administrative acquisitions}

A second feature of New Zealand's constitutional development during the first half of the twentieth century was the expansion of its territorial boundaries and administrative influence. In 1863 the boundaries of what was then the Colony of New Zealand included the three main islands (North, South, and Stewart), their immediate outliers, and the Three Kings Islands, the Snares, the Chathams, the Bounty Islands, the Antipodes Islands, the Auckland Islands, and Campbell Island. ${ }^{28}$ What is sometimes forgotten is that since 1901 there has been more to New Zealand than these islands alone. ${ }^{29}$

At the turn of the twentieth century the Colony of New Zealand had colonial ambitions of its own. Premier Richard Seddon made a series of parliamentary speeches in early 1900 in which he advocated the extension of New Zealand's territorial boundaries to include its South Pacific island neighbours. ${ }^{30}$ His sense of centenary optimism is clear: ${ }^{31}$

26 Statistics New Zealand New Zealand Official Yearbook 2000 (David Bateman, Auckland, 2000) 55.

27 Geoffrey Marston and Peter DG Skegg "The Boundaries of New Zealand in Constitutional Law" (1988) 13 NZULR 1, 2.

28 See the New Zealand Boundaries Act 1863 (UK), s 2 and the discussion in Marston and Skegg, above, 4.

29 This paper ignores the maritime areas surrounding New Zealand, the Cook Islands, Niue, Tokelau, and the Ross Dependency. See Marston and Skegg, above, 34-53.

30 See Ministry of Justice and Ministry of Pacific Island Affairs Pacific Peoples' Constitutional Report (Wellington, 2000) 16-17.

31 Premier Richard Seddon (1900) 114 NZPD 423, 425. 
There is the cruiser Mildura in our harbour buoyant and ready. Her engines are throbbing. She is tearing at the hawser. She wants to get away as the message of peace and expansion. What is her mission? Her mission is to help you, to help this colony, and to help the Empire ... . We are commencing a new century, and with its dawn let us commence a new life - one of expansion and on the forward path of our ultimate destiny .... . Our dear old flag will for ever float over the islands insuring justice and freedom to all.

In May 1900 Seddon embarked on a tour of Tonga, Fiji, Niue, and the Cook Islands, in a bid to persuade island leaders of the benefits of annexation. ${ }^{32}$ His efforts bore some fruit in 1901, when, under an imperial Order in Council of 13 May and a Proclamation of 10 June, New Zealand annexed the Cook Islands and Niue, bringing them within its boundaries and administering them as dependent territories. ${ }^{33}$

Thirteen years later, and only eleven days into the First World War, New Zealand forces captured Western Samoa from the German authorities. ${ }^{34}$ After the war, a League of Nations mandate was conferred on New Zealand for the administration of Western Samoa, which after 1945 became a United Nations Trust Territory. ${ }^{35}$

New Zealand administrative control also extended southwards. In 1923, at the insistence of an imperial Government anxious to bring the whole of Antarctica within His Majesty's authority, ${ }^{36}$ New Zealand took over administration of a territory now known as the Ross Dependency. ${ }^{37}$ Unlike New Zealand's other dependent territories, the Ross Dependency has never been brought within the boundaries of New Zealand.

The last of New Zealand's territorial acquisitions was Tokelau. The islands of the Tokelau Group became a British protectorate in 1877, were included in the Gilbert and Ellice Islands Colony in 1916, and came under New Zealand administrative control in $1926 .{ }^{38}$ Twenty-two years later,

32 Ministry of Justice and Ministry of Pacific Island Affairs, above, 17. See also Malcolm McKinnon (ed) New Zealand Historical Atlas (Bateman, Auckland, 1997) plate 82

33 See Geoffrey Marston and Peter DG Skegg "The Boundaries of New Zealand in Constitutional Law" (1988) 13 NZULR 1, 9-11, 14.

34 Ministry of Justice and Ministry of Pacific Island Affairs, above, 17-18.

35 John L Robson New Zealand: The Development of its Laws and Constitution (2 ed, Stevens, London, 1967) 21

36 See generally Malcolm Templeton A Wise Adventure: New Zealand in Antarctica 1920-1960 (Victoria University Press, Wellington, 2000) ch II.

37 See Geoffrey Marston and Peter DG Skegg "The Boundaries of New Zealand in Constitutional Law" (1988) 13 NZULR 1, 26-34

38 See Tony H Angelo "Tokelau — its Legal System, and Recent Legislation" (1987) 6 Otago LR 477, 477478. 
when it was decided to extend New Zealand citizenship to Tokelauans, ${ }^{39}$ Tokelau was brought within the boundaries of New Zealand. ${ }^{40}$ It remains a dependent territory of New Zealand.

As a result of these territorial and administrative acquisitions, New Zealand in the early 1950s was a realm of more than just metropolitan New Zealand. But the story does not end there. Selfdetermination was in the wind, and in the 1960s New Zealand became a pioneer in the application of the principles of the United Nations decolonisation programme to the small and scattered non-selfgoverning territories of the South Pacific. ${ }^{41}$ One result was that Western Samoa, the Cook Islands, and Niue became self-governing; another was the development of the Realm of New Zealand.

\section{B 1961-1983}

\section{Decolonisation}

The first island territory to leave New Zealand administrative control was Western Samoa, which became independent in 1961. Now the Independent State of Samoa, it retains close links with New Zealand under a Treaty of Friendship. ${ }^{42}$ Among other things, the terms of the Treaty provide that the New Zealand Government will consider sympathetically requests from the Government of Samoa for technical, administrative, and other assistance. ${ }^{43}$

Next to go was the Cook Islands, in $1965 .{ }^{44}$ Unlike Western Samoa, it did not become fully independent, but instead moved to a status of self-government in free association with New Zealand, signified by its continued recognition of the Queen in right of New Zealand as Head of State. ${ }^{45}$

Niue followed suit in 1974, emerging as a self-governing state in free association with New Zealand. ${ }^{46}$ Just like the Cook Islands had done, it retained the Queen in right of New Zealand as its Head of State. ${ }^{47}$

39 Marston and Skegg, above, 24.

40 See the Tokelau Act 1948 (NZ), s 3

41 Ministry of Justice and Ministry of Pacific Island Affairs Pacific Peoples' Constitutional Report (Wellington, 2000) 21-23.

42 See Ministry of Foreign Affairs and Trade <http://www.mfat.govt.nz/foreign/regions/pacific/ country/samoapaper.html $>$ (last accessed 23 July 2002).

43 See Alison Quentin-Baxter "The Independence of Western Samoa — Some Conceptual Issues" (1987) 17 VUWLR 345, 360-361.

44 See the Cook Islands Constitution Act 1964 (NZ), s 1(2) and Cook Islands Constitution Act Commencement Order 1965 (SR 1965/128), cl 2.

45 See the Constitution of the Cook Islands, art 2 and Alison Quentin-Baxter's discussion of the constitutional link in The Laws of New Zealand (Butterworths, Wellington, 2001) Pacific States and Territories: Cook Islands, para 10, 24-25, para 27, 55-60. 
The instruments under which the Cook Islands and Niue were annexed in 1901 have never been revoked, so it is arguable that they both still lie within the boundaries of New Zealand. ${ }^{48}$ Be that as it may, what is significant is that their constitutional relationship with New Zealand has changed. On becoming self-governing the Cook Islands and Niue continued to recognise the Sovereign in right of New Zealand as Head of State. But self-government meant that they were distinct from New Zealand as an administrative entity. A new account of New Zealand's macroconstitutional arrangements was called for, one that could accommodate Cook Islands and Niuean selfgovernment under a shared Head of State.

\section{A Realm of New Zealand}

It was not until 1983 that the constitutional implications of Cook Islands and Niuean selfgovernment in free association with New Zealand were fully recognised. As part of her overhaul of the 1917 Letters Patent constituting the office of Governor-General, Alison Quentin-Baxter, then Legal Consultant to the Prime Minister's Department, came up with the following formula: ${ }^{49}$

We do hereby constitute, order, and declare that there shall be, in and over Our Realm of New Zealand, which comprises-

(a) New Zealand; and

(b) The self-governing state of the Cook Islands; and

(c) The self-governing state of Niue; and

(d) Tokelau; and

(e) The Ross Dependency,-

a Governor-General and Commander-in-Chief who shall be Our representative in Our Realm of New Zealand $[\ldots]$.

The structure indicated by this provision, from the Letters Patent of 1983, in one sense reflects a fait accompli — the splitting of New Zealand as administrative entity from New Zealand as realm of the Sovereign in right of New Zealand. But the structure was novel in that for the first time there could be said to be a Realm of New Zealand with a capital 'R'.

46 See the Niue Constitution Act 1974 (NZ), s 1(2) and Niue Constitution Act Commencement Order 1974 (SR 1974/286), cl 2.

47 See the Constitution of Niue, art 1.

48 See Geoffrey Marston and Peter DG Skegg "The Boundaries of New Zealand in Constitutional Law" (1988) 13 NZULR 1, 21-23.

49 Letters Patent Constituting the Office of Governor-General of New Zealand (SR 1983/225), cl I. 
The Realm of New Zealand shares its Head of State with fifteen other realms: Antigua and Barbuda, Australia, the Bahamas, Barbados, Belize, Canada, Grenada, Jamaica, Papua New Guinea, St Christopher (Kitts) and Nevis, St Lucia, St Vincent and the Grenadines, the Solomon Islands, Tuvalu, and the United Kingdom. ${ }^{50}$ Allowance is made for these multiple realms in Her Majesty's current style and titles for use in New Zealand: ${ }^{51}$

Elizabeth the Second, by the Grace of God Queen of New Zealand and Her Other Realms and

Territories, Head of the Commonwealth, Defender of the Faith.

A single person, Queen Elizabeth II, is Queen of all sixteen realms. But the Crown (in the sense of the Sovereign herself, rather than the executive $)^{52}$ is a divisible one - a different legal entity in each realm. Unlike Her Majesty's other realms, however, the Realm of New Zealand has no international legal personality and is not itself a State. It has instead been described as a 'concept',53 a 'symbolic term' that reflects the shared history, values, and Head of State of its constituent parts. ${ }^{54}$

By the late 1950s it would have been accurate to say that New Zealand, including the Cook Islands, Niue, Tokelau, and the Ross Dependency, was a realm, called 'New Zealand'. But things have changed. There is now a Realm of New Zealand, of which New Zealand itself is only one element. This subtle but significant reframing of New Zealand's macroconstitutional arrangements has taken root in the Interpretation Act 1999 (NZ): ${ }^{.5}$

"New Zealand" or similar words referring to New Zealand, when used as a territorial description, mean the islands and territories within the Realm of New Zealand; but do not include the self-governing State of the Cook Islands, the self-governing State of Niue, Tokelau, or the Ross Dependency.

All of which makes the following statement, from the Government House publication The Role of the Governor-General of New Zealand, distinctly misleading: ${ }^{56}$

50 See the British Monarchy website <http://www.royal.gov.uk/output/page345.asp > (last accessed 3 March 2003)

51 Royal Titles Act 1974 (NZ), s 2.

52 See Halsbury's Laws of England (4 ed reissue, Butterworths, London, 1998) vol 12(1), Crown and Royal Family, paras 1, 3 .

53 Alex Frame "Fundamental Rights in the Realm of New Zealand: Theory and Practice" (1992) 22 VUWLR (Monograph 4) 85, 85.

54 Interview with HE Hon Dame Silvia Cartwright PCNZM DBE, Governor-General of New Zealand (the author, Wellington, 31 July 2002).

55 Interpretation Act 1999 (NZ), s 29.

56 The Role of the Governor-General of New Zealand (Government House, Wellington, 2002) 6. 
New Zealand is an independent sovereign nation. Because we are a monarchy, our country is styled a "Realm". The Realm of New Zealand comprises New Zealand, Tokelau and the Ross Dependency, and the self-governing states of the Cook Islands and Niue.

\section{SELF-GOVERNMENT IN FREE ASSOCIATION WITH NEW ZEALAND}

As observed earlier, the Cook Islands made its act of self-determination in 1965, and Niue in 1974. Since then, they have tended to move in opposite directions: ${ }^{57}$

The Cook Islands and New Zealand, often wanting to go their separate ways, have had to accommodate themselves to the fact that they are not in the relationship of two independent states. Niue [on the other hand] has had to fight against the idea that it should be treated as though it had become independent.

In the Cook Islands context, self-government in free association means something much closer to independence than it does in Niue. But the essence of the free association relationship, enshrined in the Cook Islands Constitution Act 1964 (NZ), the Niue Constitution Act 1974 (NZ), and the Constitutions of the Cook Islands and Niue, ${ }^{58}$ is common to both. Its six main facets are discussed below.

\section{A The Shared Head of State}

As constituent elements of the Realm of New Zealand, New Zealand, the Cook Islands, and Niue share the same Queen as Head of State: ${ }^{59}$

The Sovereign in right of New Zealand is the Head of State of New Zealand .... .

Her Majesty the Queen in right of New Zealand shall be the Head of State of the Cook Islands.

The executive authority of Niue is vested in Her Majesty the Queen in right of New Zealand ....

The shared Head of State forms a constitutional link between New Zealand and the Cook Islands and Niue, symbolising the relationships of free association. But while each State shares the same Queen, the manner in which she is represented within the Realm varies from one to another.

The Sovereign's representative in New Zealand is the Governor-General of New Zealand: ${ }^{60}$

57 Alison Quentin-Baxter "Niue's Relationship of Free Association with New Zealand" (1999) 30 VUWLR $589,593$.

58 See The Laws of the Cook Islands 1997 (The Crown in Right of the Cook Islands, Rarotonga, 1997); Ko $e$ Fakatufono-Tohi Fakave ha Niue - the Constitution of Niue (compiled by Tony H Angelo, Faculty of Law, Victoria University of Wellington, Wellington, 1997).

59 Constitution Act 1986 (NZ), s 2(1); Constitution of the Cook Islands, art 2; Constitution of Niue, art 1.

60 Letters Patent Constituting the Office of Governor-General of New Zealand (SR 1983/225) cl I. 
We do hereby constitute, order, and declare that there shall be, in and over Our Realm of New Zealand, ... a Governor-General and Commander-in-Chief who shall be Our representative in Our Realm of New Zealand ....

The Governor-General derives her position as the Sovereign's representative in New Zealand from the fact that she is the Sovereign's representative for the whole of the Realm, of which New Zealand is one constituent element.

In Niue, things are more direct. The Governor-General is the Sovereign's representative in Niue not by virtue of her position as Governor-General for the Realm, but because the Constitution of Niue, which is the supreme law of Niue, ${ }^{61}$ says so. ${ }^{62}$

$[\mathrm{T}]$ he Governor-General of New Zealand is ... the representative of Her Majesty the Queen in relation to Niue.

The situation is different again in the Cook Islands, in which the Queen is represented separately: ${ }^{63}$

There shall be a representative of Her Majesty the Queen in the Cook Islands, to be known as the Queen's Representative.

The existence of a separate Queen's representative in the Cook Islands is allowed for by the Letters Patent, under which the Governor-General may exercise her powers and authorities "without prejudice to the office, powers, or authorities of any other person who has been or may be appointed to represent [Her Majesty the Queen] in any part of [Her] Realm of New Zealand and to exercise powers and authorities on [Her] behalf". ${ }^{64}$ But what the Letters Patent do not explain is the relationship between the Governor-General and the Queen's Representative.

In form, the Cook Islands has two Queen's representatives — one (the Queen's Representative) for the Cook Islands as Cook Islands; the other (the Governor-General) for the Cook Islands as part of the Realm of New Zealand. This arrangement is akin to those of Australia and Canada, where the Governor-General is the Sovereign's representative for the whole of the federation but each State or Province retains its own Governor or Lieutenant-Governor to represent the Queen in that State or Province. ${ }^{65}$ The Governor-General is Governor-General in the Cook Islands, notwithstanding the

61 Niue Constitution Act 1974 (NZ), s 4.

62 Constitution of Niue, art 1.

63 Constitution of the Cook Islands, art 3(1).

64 Letters Patent Constituting the Office of Governor-General of New Zealand (SR 1983/225), cl I.

65 Alison Quentin-Baxter The Laws of New Zealand (Butterworths, Wellington, 2001) Pacific States and Territories: Cook Islands, para 27, 56-57; Alison Quentin-Baxter Review of the Letters Patent 1917 Constituting the Office of Governor-General of New Zealand (report to the Prime Minister's Department, 
fact that her powers and authorities there are different from her powers and authorities in New Zealand, or in Niue. The role as such does not depend on what powers and authorities she may or may not have in the various parts of the Realm. There could be none, and she would still be Governor-General. ${ }^{66}$

In substance, though, the relationship between the Governor-General and the Queen's Representative is quite different. Under the Cook Islands' comprehensive written constitution, executive power is vested in local institutions, leaving the Governor-General with only an indirect constitutional role in the form of the defence and external affairs prerogatives, arising from the Governor-General's constitutional position in terms of the Realm as a whole. In effect, any viceregal powers and responsibilities are vested in the Queen's Representative, leaving the GovernorGeneral with no substantive role in relation to the Cook Islands.

\section{B Self-Government}

The second term of the relationships of free association is stated in plain terms in the Cook Islands and Niue Constitution Acts: ${ }^{67}$

The Cook Islands shall be self-governing.

Niue shall be self-governing.

One aspect of Cook Islands and Niuean self-government is that their legislatures have full and exclusive power to make laws. ${ }^{68}$ Another aspect is that their Governments have plenary powers in respect of Cook Islands and Niuean matters. Put another way, the Crown in right of New Zealand (in the sense of the executive, rather than the Sovereign) is a divisible one.

In the federal realms of Australia and Canada, the Crown as executive is divisible among the States or Provinces. ${ }^{69}$ 'The Crown' in South Australia is a different legal entity from 'the Crown' in New South Wales, and 'the Crown' in Saskatchewan a different legal entity from 'the Crown' in Nova Scotia. Unlike Australia and Canada, the Realm of New Zealand is not a State. But its basic structure is otherwise essentially the same: an association of States and Territories recognising a

Cabinet Office, Wellington, 1980) 134; Donald L Stevens The Crown, the Governor-General, and the Constitution (LLM(Hons) Thesis, Victoria University of Wellington, 1974) 26.

66 Alison Quentin-Baxter Review of the Letters Patent 1917 Constituting the Office of Governor-General of New Zealand, above, 135.

67 Cook Islands Constitution Act 1964 (NZ), s 3; Niue Constitution Act 1974 (NZ), s 3.

68 Alex Frame "Fundamental Rights in the Realm of New Zealand: Theory and Practice" (1992) 22 VUWLR (Monograph 4) 85, 85.

69 See generally Peter W Hogg Liability of the Crown (2 ed, Carswell, Toronto, 1989) 10-12. 
single sovereign as Head of State,$^{70}$ and in which the Crown as executive is divisible among those States and Territories. ${ }^{71}$ There is only one Queen in right of (the Realm of) New Zealand, and in Realm matters she or her Governor-General is advised by the Executive Council. ${ }^{72}$ But in matters relating to any one State within the Realm she is advised separately by her Ministers in that State. ${ }^{73}$ Hence, while it would be inappropriate to refer to the Queen in right of the Cook Islands (because the Cook Islands is not a realm), it is possible to speak of the Crown in right of the Cook Islands, or the Crown in right of the Government of the Cook Islands. ${ }^{74}$

\section{The Common Citizenship}

Perhaps the most widely-understood term of the relationships of free association is that Niueans and Cook Islanders enjoy New Zealand citizenship, the primary benefit of which is that they are free to travel between the islands and New Zealand. ${ }^{75}$ The common citizenship is something of a doubleedged sword. ${ }^{76}$ It is useful if one wants to visit family on 'the mainland', or work, or attend university, or get specialist hospital care. But it has tended in recent years to encourage population decline, because it allows anyone who wants to leave the islands and settle in New Zealand to do so. This places considerable stresses on the already small local populations of the Cook Islands and Niue. Nevertheless, it seems unthinkable that Cook Islanders or Niueans would want their eligibility for New Zealand citizenship to be discontinued. It is particularly highly valued in Niue: ${ }^{77}$

Niueans still place an extremely high value on their New Zealand citizenship. Its value extends beyond unfettered access to New Zealand. For almost 100 years New Zealand has been the point of reference for Niueans in matters social, economic and political. New Zealand is also the Niuean's yardstick for

70 Geoffrey Marston and Peter DG Skegg "The Boundaries of New Zealand in Constitutional Law" (1988) 13 NZULR 1, 33.

71 Alison Quentin-Baxter The Laws of New Zealand (Butterworths, Wellington, 2001) Pacific States and Territories: Cook Islands, para 27, 55, para 10, 24-25.

72 Letters Patent Constituting the Office of Governor-General of New Zealand (SR 1983/225) cl VII.

73 See the Joint Centenary Declaration of the Principles of the Relationship Between New Zealand and the Cook Islands (11 June 2001) cl 3(1). The text of the Joint Centenary Declaration can be found at Ministry of Foreign Affairs and Trade <http:/www.mfat.govt.nz/foreign/regions/pacific/cookislandseclaration/ cooksdec.html $>$ (last accessed 17 July 2002). See also, in relation to Niue, Ministry of Foreign Affairs and Trade <http://www.mfat.govt.nz/foreign/regions/pacific/country/niuepaper.html > (last accessed 17 July 2002).

74 See for example the copyright declaration in The Laws of the Cook Islands 1997 (The Crown in right of the Cook Islands, Rarotonga, 1997).

75 Cook Islands Constitution Act 1964 (NZ), s 6; Niue Constitution Act 1974 (NZ), s 5.

76 Interview with HE Hima Takelesi, High Commissioner for Niue (the author, Wellington, 31 July 2002).

77 First Report of the Constitutional Review Committee (Niue Constitutional Review Committee, December 2000) 22 . 
measuring the quantum and quality of their standard of life. New Zealand citizenship is in a sense seen by the people as their best insurance policy.

\section{Economic and Administrative Assistance}

A further term of New Zealand's free association relationship with Niue is that New Zealand has an obligation to provide 'necessary economic and administrative assistance' to Niue. ${ }^{78}$ Though there has been some divergence of opinion over what 'necessary' assistance amounts to in practice, ${ }^{79}$ this term otherwise speaks for itself, to the tune of $\$ 3.75$ million in budgetary support and $\$ 2.5$ million for development projects in the year 2001-2002. ${ }^{80}$

It has been argued that this term is also implied in the Cook Islands Constitution, since the Cook Islands Constitution Act was enacted by the New Zealand Parliament on the understanding of both Governments that Cook Islands self-government would not affect the continuation of existing financial assistance. ${ }^{81}$ In the year 2001-2002 the Cook Islands received \$6.2 million in development project support from the New Zealand Government. ${ }^{82}$

\section{E Defence and Foreign Affairs}

Another term of the free association relationships relates to defence and foreign affairs. Both the Cook Islands Constitution Act 1964 and the Niue Constitution Act 1974 state that nothing in them or in the Constitutions shall affect "the responsibilities of Her Majesty the Queen in right of New Zealand" for the external affairs and defence of the Cook Islands and Niue. ${ }^{83}$ Despite the implication in the word 'responsibilities' that these matters might be beyond the control of the Cook Islands and Niue Governments, the prevailing view is that external affairs and defence powers can only be exercised by New Zealand at their request and on their behalf. ${ }^{84}$

78 Niue Constitution Act 1974 (NZ), s 7

79 See Alison Quentin-Baxter "Niue's Relationship of Free Association with New Zealand" (1999) 30 VUWLR 589, 595-598; First Report of the Constitutional Review Committee, above, 28-34.

80 See Ministry of Foreign Affairs and Trade <http://www.mfat.govt.nz/foreign/regions/pacific/ country/niuepaper.html> (last accessed 17 July 2002).

81 Alison Quentin-Baxter The Laws of New Zealand (Butterworths, Wellington, 2001) Pacific States and Territories: Cook Islands, paras 31, 74-78.

82 See Ministry of Foreign Affairs and Trade <http://www.mfat.govt.nz/foreign/regions/pacific/ country/cookislandspaper.html $>$ (last accessed 17 July 2002).

83 Cook Islands Constitution Act 1964 (NZ), s 5; Niue Constitution Act 1974 (NZ), s 6.

84 See the Joint Centenary Declaration of the Principles of the Relationship Between New Zealand and the Cook Islands (11 June 2001), cls 4, 7; First Report of the Constitutional Review Committee (Niue Constitutional Review Committee, December 2000) 24; Alex Frame "The External Affairs and Defence of the Cook Islands - the 'Riddiford Clause' Considered" (1987) VUWLR 141, 141-151; Alison QuentinBaxter The Laws of New Zealand, above, paras 12, 28, 29, 63-74. 
New Zealand's external affairs responsibilities in relation to the Cook Islands have steadily decreased since 1965. The Cook Islands now enters into treaties in its own name, has become a member of a number of regional and international organisations, and has established diplomatic relations with eighteen countries, including the United Kingdom, the Federal Republic of Germany, and the United States of America. ${ }^{85}$ In this respect, it has developed further than Niue. ${ }^{86}$ But as long as the Cook Islands remains a State in free association with New Zealand, New Zealand will necessarily have a role in the conduct of its external affairs, not least in representing the Cook Islands in the United Nations.

\section{F Cooperation, Consultation, and a Commitment to Shared Values}

The terms of the relationships of free association sit against a background of cooperation and consultation. The Niue Constitution Act provides that: ${ }^{87}$

[e]ffect shall be given to the [external affairs and defence, and economic and administrative assistance] provisions of this Act, and to any other aspect of the relationship between New Zealand and Niue which may from time to time call for positive co-operation between New Zealand and Niue, after consultation between the Prime Minister of New Zealand and the Premier of Niue ....

Similarly, the Joint Centenary Declaration signed by the Governments of New Zealand and the Cook Islands in June 2001 recommends that: ${ }^{88}$

all issues affecting the two countries ... be resolved on a cooperative and consultative basis.

In addition to these principles of cooperation and consultation, the relationships of free association, and particularly the shared citizenship, are founded upon shared values. This aspect of the relationships has been expressed most recently in the Joint Centenary Declaration, which, in a statement that is equally true of Niue, ${ }^{89}$ provides that: ${ }^{90}$

85 See Ministry of Foreign Affairs and Trade <http://www.mfat.govt.nz/foreign/regions/pacific/ country/cookislandspaper.html $>$ (last accessed 17 July 2002).

86 See Ministry of Foreign Affairs and Trade <http://www.mfat.govt.nz/foreign/regions/pacific/ country/niuepaper.html> (last accessed 17 July 2002).

87 Niue Constitution Act 1974 (NZ), s 8.

88 Joint Centenary Declaration of the Principles of the Relationship Between New Zealand and the Cook Islands (11 June 2001) cl 1. See also cls 4 (foreign affairs) and 7 (defence and security).

89 See Alison Quentin-Baxter "Niue's Relationship of Free Association with New Zealand" (1999) 30 VUWLR 589, 590, 593.

90 Joint Centenary Declaration of the Principles of the Relationship Between New Zealand and the Cook Islands (11 June 2001) cl 2(1). 
[t]he people of the Cook Islands will retain New Zealand citizenship, respecting and upholding the fundamental values on which that citizenship is based. The Cook Islands and New Zealand share a mutually acceptable standard of values in their laws and policies, founded on respect for human rights, for the purpose and principles of the United Nations Charter, and for the rule of law.

\section{A LOPSIDED REALM}

In principle, New Zealand as administrative entity is quite separate from New Zealand as realm of the Sovereign. As the structure set out in the Letters Patent indicates, New Zealand and the Realm of New Zealand are not the same thing. But when it comes to how the Realm operates in practice, there is a noticeable New Zealand bias.

\section{A The Governor-General}

One aspect of New Zealand's privileged position within the Realm of New Zealand concerns the nationality and appointment of the Governor-General. Since 1967 New Zealand Governors-General have been New Zealanders. ${ }^{91}$ No longer are they British aristocrats. Nor has New Zealand yet seen a Cook Islander or a Niuean (or indeed, a Tokelauan) fulfilling the role of Queen's representative for the Realm of New Zealand. By convention, the Governor-General is appointed by the Queen on the advice of the New Zealand Government. Niue and the Cook Islands are advised of the appointment, but have no say in it, ${ }^{92}$ even though the Governor-General is formally as much theirs as she is New Zealand's.

Niue is happy with these lopsided arrangements as long as appointees continue to be competent and well-briefed in Niue affairs, and the office is maintained at New Zealand's expense. ${ }^{93}$ As for the Cook Islands, the general perception is that the Queen's Representative is the Queen's only representative in the Cook Islands, whereas the Governor-General is seen as belonging to New Zealand. ${ }^{94}$ So it is presumably of little concern to the Cook Islands Government that it does not have a say in who is appointed Governor-General, and that appointees are always New Zealanders by nationality as well as citizenship.

The Executive Council is the body by which the Governor-General and the Queen are formally advised in the government of New Zealand and through which executive decisions are given legal

91 Philip A Joseph Constitutional and Administrative Law in New Zealand (2 ed, Brookers, Wellington, 2001) 147.

92 Interview with HE Hima Takelesi, High Commissioner for Niue (the author, Wellington, 31 July 2002); interview with Audrey Brown-Pereira, Acting High Commissioner for the Cook Islands (the author, Wellington, 6 August 2002).

93 Interview with HE Hima Takelesi, High Commissioner for Niue (the author, Wellington, 31 July 2002).

94 Interview with Audrey Brown-Pereira, Acting High Commissioner for the Cook Islands (the author, Wellington, 6 August 2002). 
effect. ${ }^{95}$ It has a long history, dating back to the Letters Patent of 1840 under which New Zealand became a separate colony from New South Wales. ${ }^{96}$ Its members are Her Majesty's (and, by implication, Her Excellency's) "responsible advisers"97 — that is, all Ministers of the Crown, most of whom are also members of Cabinet. In effect the Executive Council is an organ of New Zealand government, analogous to the Executive Council of the Cook Islands. ${ }^{98}$

But the Executive Council also has the function of advising the Governor-General in the government of the Realm as a whole. ${ }^{99}$ Similarly, it is New Zealand Ministers who are to keep the Governor-General informed as to the general government of the Realm. ${ }^{100}$ These provisions can be explained on the basis that the Realm as an institution resides in New Zealand, and is predominantly concerned with New Zealand business. (It is presumably for the same reason that it is New Zealand judges who are to act as Administrator of the Government in the Governor-General's absence). ${ }^{101}$ But their effect is that matters relating to the Realm as a whole, or to parts of it other than New Zealand, are channelled to the Governor-General via New Zealand Ministers. One such matter is the use of the Seal of New Zealand, used for the authentication of official documents taking effect in the whole of the Realm, ${ }^{102}$ such as the Letters Patent. This power can be exercised only by the Governor-General in Council (or the Queen in Council), ${ }^{103}$ which rules out the formal input of Niuean and Cook Islands Ministers. In this way the composition of the Executive Council interferes with the principle that the Crown in right of New Zealand is a divisible one whereby Niue and the Cook Islands are self-governing.

\section{B The Tendering of Advice to the Sovereign}

While it is said that Her Majesty is advised in Cook Islands and Niuean matters by her Cook Islands and Niue Ministers alone, when it comes to advising the Queen on a suggested appointment

95 See Philip A Joseph Constitutional and Administrative Law in New Zealand (2 ed, Brookers, Wellington, 2001) 717-725.

96 Joseph, above, 717.

97 See the Letters Patent Constituting the Office of Governor-General of New Zealand (SR 1983/225) cl VIII, as amended by the Letters Patent amending Letters Patent constituting the Office of Governor-General of New Zealand (SR 1987/8).

98 As to which see the Constitution of the Cook Islands, art 22.

99 Letters Patent Constituting the Office of Governor-General of New Zealand (SR 1983/225) cl VII.

100 Letters Patent Constituting the Office of Governor-General of New Zealand (SR 1983/225) cl XVI.

101 Letters Patent Constituting the Office of Governor-General of New Zealand (SR 1983/225) cl XII.

102 Seal of New Zealand Act 1977 (NZ), s 2(1).

103 Seal of New Zealand Act 1977 (NZ), s 3; Constitution Act 1986 (NZ), s 3; Constitutional Provisions Act 1982 (Niue), s 4. 
for the position of Queen's Representative in the Cook Islands, the Cook Islands Government must route its advice via the New Zealand Prime Minister and the Governor-General, under the so-called 'six-step procedure'. ${ }^{104}$ The procedure is followed ostensibly to ensure that the Queen does not get different advice from different parts of her realm, ${ }^{105}$ though it also hints at an underlying paternalism on the part of the New Zealand Government. The Queen's Representative is Her Majesty's representative for the Cook Islands alone. Why should the New Zealand Government have any role in the appointment process? The six-step procedure would presumably cease if New Zealand were to become a republic.

A similar practice to the six-step procedure is observed for Cook Islands and Niuean nominations for royal honours. ${ }^{106}$ In what appears to be a matter of mutual convenience, making use of the expertise of the New Zealand Honours Secretariat, nominations are channelled to the Palace via the New Zealand Prime Minister and Governor-General.

\section{Miscellaneous Borrowings}

Besides the shared Head of State and the other terms of the free association relationships, the legal systems of the Cook Islands and Niue are linked to New Zealand's in a number of other respects.

\section{The Judiciary}

One of these borrowings relates to the judiciary. Under the Constitution of the Cook Islands, the Cook Islands High Court may comprise New Zealand High Court and Court of Appeal judges, and the Court of Appeal must contain at least one New Zealand High Court or Court of Appeal judge. ${ }^{107}$ While not expressly provided for in the Niue Constitution, New Zealand judges sit from time to time on Niuean courts also. The small local legal fraternity in the Cook Islands and Niue makes the borrowing of judges from New Zealand necessary, and this arrangement could quite legitimately continue if New Zealand were no longer part of the Realm, since the judges are appointed as Cook Islands and Niuean judges. ${ }^{108}$ It would no longer be appropriate, however, to maintain New Zealand judges' current exemption from having to recite the Cook Islands oath of allegiance and judicial oath. ${ }^{109}$

104 See Alison Quentin-Baxter The Laws of New Zealand (Butterworths, Wellington, 2001) Pacific States and Territories: Cook Islands, paras 9, 23, 11, 26, 27, 55.

105 The Laws of New Zealand, above, paras 27, 55.

106 Thanks for explication of this point to Phillip O'Shea LVO, New Zealand Herald of Arms Extraordinary.

107 Constitution of the Cook Islands, arts 49, 56.

108 Constitution of the Cook Islands, art 52; Constitution of Niue, arts 42, 45, 52, 55C.

109 Constitution of the Cook Islands, art 63. 


\section{Legislation}

Another borrowing arrangement relates to legislation in Niue. The New Zealand Parliament and the Governor-General in Council may legislate for Niue, but only at the request and with the consent of the Niue Assembly (in the case of New Zealand Acts) or the Cabinet (in the case of subordinate legislation). ${ }^{110}$ The same arrangement was originally provided for in the Cook Islands Constitution, but was abolished in 1981. ${ }^{111}$

It would be odd if the ability of New Zealand institutions to legislate for Niue were retained if New Zealand became a republic. It appears that only three New Zealand statutes have been extended to Niue since $1974,{ }^{112}$ and a regulation-making power is conferred on the Governor-General in Council by only a handful of Acts. ${ }^{113}$ Nevertheless, the enactment in 1998 of a statute purporting to extend to Niue all future amendments to the Misuse of Drugs Act 1975 (NZ) without request or consent on each occasion suggests a willingness on the part of the Niue legislature to leave regulatory legislation to the Parliament of New Zealand. ${ }^{114}$

\section{The Audit Office}

A further and more prosaic feature of the Constitution of Niue is that the Audit Office of New Zealand acts as the Niue Government's official auditor. ${ }^{115}$ There would be no reason for this arrangement not to continue if New Zealand were to become a republic.

\section{A NEW ZEALAND REPUBLIC}

Miscellaneous borrowings by the Cook Islands and Niue aside, there are difficult legal issues surrounding any move to a republic in New Zealand. ${ }^{116}$ Some of the thorniest relate to the unwritten rules of the constitution - the conventions that guide such crucial matters as the relationship between the Governor-General and Ministers, the formation of the Government after an election, and the appointment of the Prime Minister. But in the end, subject only to the obligations of cooperation and consultation under the free association relationships with the Cook Islands and

110 Constitution of Niue, art 36.

111 See the Constitution of the Cook Islands, art 46; Constitution Amendment (No 9) Act 1980-1981 (CI), s 5.

112 Misuse of Drugs Act 1975 (NZ), Citizenship Act 1977 (NZ), Seal of New Zealand Act 1977 (NZ).

113 See for example the United Nations Act 1946 (NZ).

114 See the Misuse of Drugs Act 1998 (Niue) and the critique of this approach in Andrew Townend "DrugsBust in Niue: the Misuse of Drugs Act 1998 and the Constitution" (2002) Revue Juridique Polynésienne numéro hors serie (vol 2) 109.

115 Constitution of Niue, art 60(1).

116 See (among others) Andrew P Stockley "Becoming a Republic? Issues of Law" in Luke Trainor (ed) Republicanism in New Zealand (Dunmore Press, Palmerston North, 1996) 81. 
Niue, New Zealand would simply go ahead and make the change, much as it abolished the Legislative Council in 1950 and, in the Constitution Act 1986, severed the New Zealand Parliament's residual link to the Parliament of the United Kingdom. ${ }^{117}$ The following section of this paper considers the effects on New Zealand's current relationship with the Cook Islands and Niue should New Zealand secede from the Realm to become a republic.

\section{A A Republic of Aotearoa New Zealand}

One likely aspect of the republican agenda would be a thorough examination of the place of the Treaty of Waitangi in a future of which the Crown would no longer play a part. While it is probably fair to say that the only relevant meaning of 'the Crown' in this context is now 'the Government', nevertheless, as Andrew Ladley points out, ${ }^{118}$

any suggestion of change would flush out a full-scale constitutional debate within Maoridom. It may be that the intensity of this would take most New Zealanders by surprise, and that it would produce uniquely New Zealand demands ... .

Those uniquely New Zealand demands make a single republic of New Zealand, the Cook Islands, and Niue an improbable proposition.

There is a nation-building aspect to the republican debate too. It pervades the writings of the Republican Movement of Aotearoa New Zealand, ${ }^{119}$ and is evident also in the comments of the Prime Minister, reported in March 2002 as having said that "the reality was that New Zealand was a fully independent sovereign state, and that its Head of State should be a New Zealander". ${ }^{120}$ The New Zealand focus of any change is also evident in Keith Locke MP's Head of State Referenda Bill, under which the change would be triggered by referenda of New Zealand electors. ${ }^{121}$ Any decision would presumably bind the Crown only in respect of New Zealand, since the Bill would not have effect in Niue or the Cook Islands.

It seems likely that on becoming a republic New Zealand would retain the Ross Dependency as a dependent territory. As for Tokelau, its relationship with a republican New Zealand would depend on the outcome of current constitutional developments. Independence is extremely unlikely, given

117 See Rt Hon Sir Robin Cooke "The Suggested Revolution Against the Crown" in Philip A Joseph (ed) Essays on the Constitution (Brookers, Wellington, 1995) 30-31, 36; Stockley, above, 98.

118 Andrew Ladley "Who should be Head of State?" in Colin James (ed) Building the Constitution (Institute of Policy Studies, Wellington, 2000) 267, 273.

119 See the Republican Movement's website, <http://www.republic.org.nz>.

120 "NZ Waiting for Australia to Make Republic Move" (3 March 2002) New Zealand Herald Online $<$ http://www.nzherald.co.nz/latestnewsstory.cfm?storyID=1090577\&thesection=news\&thesubsection=gener al\&thesecondsubsection=latest $>$ (last accessed 3 March 2003).

121 Keith Locke MP Head of State Referenda Bill, cls 3-6. 
its tiny population (approximately 1,500) and scarce resources. ${ }^{122}$ But some kind of selfgovernment in free association with New Zealand could be a viable option, as could integration. The material presented in this paper will be more or less relevant to Tokelau depending on where it stands should New Zealand become a republic.

\section{B An End to the Shared Head of State}

The tenor of the republican debate so far suggests that New Zealand would be unlikely to want to share a future president with the Cook Islands or Niue. Nor would the amendment of New Zealand law to allow for a president have any effect in the law of the Cook Islands or Niue.

It does not seem, in any case, that the Cook Islands would want to share New Zealand's new Head of State, having terminated all shared macroconstitutional arrangements except the existing Head of State herself. ${ }^{123}$

Niue, on the other hand, seems quite keen on the idea. It considers itself more pragmatic than the Cook Islands. ${ }^{124}$ Nice as it is to have nationalistic aspirations, sharing the Head of State with New Zealand has served Niue well. Apart from anything else, it costs the Niue Government nothing. Niueans identify well with the Governor-General, ${ }^{125}$ and treated her with the "utmost respect" during her visit in 2001 as part of the celebrations marking the centenary of the link between Niue and New Zealand. ${ }^{126}$

The self-centredness of republican discussions in New Zealand to date may be due to a general ignorance about New Zealand's constitutional links with the Cook Islands and Niue - the 'gap in the republican debate' referred to in the introduction to this paper. It could in fact be possible to accommodate Niue within New Zealand's future constitutional arrangements without spoiling the republican party, perhaps by making clear that the president was to be borrowed by Niue, rather than shared with it. Nor would it be all that strange if Niue were to adopt New Zealand's new Head of State. After all, it shares New Zealand's Head of State now. And if Andorra can have as its co-heads of state the President of France and the Bishop of Urgell, surely Niue could have the President of New Zealand. While unlikely, a modified status quo for Niue will be preserved as one of the options described in part VIII of this paper.

122 See LJ Watt "Report of the Administrator of Tokelau for the year ended 30 June 1998" [1997-1998] AJHR E14 4.

123 Alison Quentin-Baxter The Laws of New Zealand (Butterworths, Wellington, 2001) Pacific States and Territories: Cook Islands, para 26, 54.

124 Interview with HE Hima Takelesi, High Commissioner for Niue (the author, Wellington, 31 July 2002).

125 Interview with HE Hima Takelesi, High Commissioner for Niue (the author, Wellington, 31 July 2002).

126 Interview with HE Hon Dame Silvia Cartwright PCNZM DBE, Governor-General of New Zealand (the author, Wellington, 31 July 2002). 


\section{ONGOING RELATIONSHIPS OF FREE ASSOCIATION}

Free association between self-governing States does not depend on a constitutional link. ${ }^{127}$ The Marshall Islands, for example, are in free association with the United States of America, but do not share their President. ${ }^{128}$ It is the terms of the Compact of Free Association that give shape to the relationship.

In the case of Niue and the Cook Islands, the constitutional link with New Zealand, symbolised in their continuing membership of the Realm of New Zealand, gives constitutional shape to the relationships of free association. But the operative terms of the relationships lie at the Governmentto-Government level, so there would be in principle no reason for the relationships not to continue if New Zealand were to become a republic, even if, as is most likely, the constitutional link were severed. It is possible that for whatever reason an irretrievable breakdown in the relationships might occur, perhaps because of a departure from the principles of cooperation, consultation, and shared values. It is also possible that the Cook Islands might at some point move to a status of full independence. But there is no sign of either of these happening in the foreseeable future - in fact, quite the opposite. The Joint Centenary Declaration between New Zealand and the Cook Islands represents the ongoing commitment of both countries to preserve the free association, ${ }^{129}$ a commitment that is similarly present between New Zealand and Niue. ${ }^{130}$ For this reason independence is not presented as one of the options for the constitutional futures of the Cook Islands and Niue in part VIII of this paper.

\section{A Administrative and Economic Support}

Section 7 of the Niue Constitution Act 1974 provides that: ${ }^{131}$

[i]t shall be a continuing responsibility of the Government of New Zealand to provide necessary economic and administrative assistance to Niue.

Of the terms of the free association relationships, the provision of economic and administrative assistance to Niue would be probably the least problematic to preserve. The wording of section 7 of

127 Alison Quentin-Baxter The Laws of New Zealand (Butterworths, Wellington, 2001) Pacific States and Territories: Cook Islands, para 27, 58. Compare Alison Quentin-Baxter Review of the Letters Patent 1917 Constituting the Office of Governor-General of New Zealand (report to the Prime Minister's Department, Cabinet Office, Wellington, 1980) 134.

128 Interview with Alison Quentin-Baxter QSO (the author, Wellington, 14 July 2002).

129 Joint Centenary Declaration of the Principles of the Relationship Between New Zealand and the Cook Islands (11 June 2001), preamble.

130 See for example the Ministry of Foreign Affairs and Trade <http://www.mfat.govt.nz/foreign/ regions/pacific/country/niuepaper.html > (last accessed 17 July 2002).

131 Niue Constitution Act 1974 (NZ), s 7. 
the Niue Constitution Act could survive a break in the constitutional link between New Zealand and Niue, so that ongoing support would hinge entirely on Niue's desire to continue receiving it and New Zealand's willingness to continue providing it. There is no evidence that that either party is likely to change its current position, though the nature and degree of assistance will require ongoing consideration.

\section{B The Common Citizenship}

The Cook Islands and Niue Constitution Acts contain identical citizenship provisions: ${ }^{132}$

Nothing in this Act or in the Constitution shall affect the status of any person as a British subject or New

Zealand citizen by virtue of the British Nationality and New Zealand Citizenship Act 1948.

Like the provision in the Niue Constitution Act relating to administrative and economic support, the wording of the citizenship provisions in the Cook Islands and Niue Constitution Acts could survive a constitutional split. But the shared citizenship has a constitutional aspect, in that it is the privilege one receives in return for allegiance to the Head of State. Should New Zealand become a republic it would most likely no longer share its Head of State with the Cook Islands and Niue. Would Cook Islanders and Niueans be able to retain New Zealand citizenship? Does the shared citizenship depend on a shared Head of State, or is it something that the Government of New Zealand has agreed to extend to the inhabitants of Niue and the Cook Islands, entirely independently of the fact that they share New Zealand's Head of State?

The New Zealand passport states that: ${ }^{133}$

[t]he Governor-General in the Realm of New Zealand requests in the Name of Her Majesty The Queen all whom it may concern to allow the holder to pass without delay or hindrance and in case of need to give all lawful assistance and protection.

By referring to the 'Governor-General in the Realm of New Zealand' rather than the 'GovernorGeneral of New Zealand' this formula suggests that the citizenship is of the Realm. But this is symbolism; what about the way citizenship actually works in practice?

Alison Quentin-Baxter has observed that the common citizenship is now a statutory creature, and not dependent upon a shared Head of State. ${ }^{134}$ It can be seen as citizenship of New Zealand, extended by statute to the Cook Islands and Niue, rather than as citizenship of the Realm. The citizenship rights of New Zealanders, Cook Islanders, and Niueans are governed by the Citizenship Act 1977, an enactment of the Parliament of New Zealand which replaced the British Nationality

132 Cook Islands Constitution Act 1964 (NZ), s 6; Niue Constitution Act 1974 (NZ), s 5.

133 New Zealand Passport 1.

134 Alison Quentin-Baxter The Laws of New Zealand (Butterworths, Wellington, 2001) Pacific States and Territories: Cook Islands, para 28, 60, 62. 
and New Zealand Citizenship Act 1948 (the reference to which in the Cook Islands and Niue Constitution Acts may be considered obsolete, and unnecessary in the first place). The Citizenship Act is in force in the Cook Islands and Niue, ${ }^{135}$ and contains a definition of 'New Zealand' that is specifically extended to include them. ${ }^{136}$

In 1973 the then Prime Minister of New Zealand, Norman Kirk, remarked to the then Premier of the Cook Islands, Albert Henry, that it is "unusual for a state to extend its citizenship to people living in areas beyond the reach of its own laws". ${ }^{137}$ It would be even more unusual if this arrangement were to continue even after New Zealand had become a republic, but there is no technical reason why it could not, in substance at least, if not in name.

Certainly, any change to the substance of current arrangements would be extremely controversial. While it might be acceptable to Cook Islanders and Niueans to institute some kind of dual citizenship, ${ }^{138}$ it would be politically risky to interfere with the New Zealand element of it. A separate citizenship would be seen as a slippery slope to complete independence and the end of the free association - a distinctly unattractive proposition. ${ }^{139}$ There are now approximately 14,000 Cook Islanders in the Cook Islands, and 2,000 Niueans in Niue, with much larger populations in New Zealand. ${ }^{140}$ The future of the Cook Islands and Niue depends on the freedom of their inhabitants to move between the islands and New Zealand.

\section{Defence and Foreign Affairs}

\section{A change to the Constitution Acts}

The defence and foreign affairs term of the relationships of free association would become problematic if New Zealand became a republic. The difficulty would stem from the wording of the relevant provisions in the Cook Islands and Niue Constitution Acts: ${ }^{141}$

135 Citizenship Act 1977 (NZ), s 29.

136 Citizenship Act 1977 (NZ), s 2 (1).

137 Exchange of Letters between the Government of New Zealand and the Government of the Cook Islands on the Constitutional Relationship between the two Countries (1973)—see Ministry of Foreign Affairs and Trade <http://www.mfat.govt.nz/foreign/regions/pacific/country/cookislandspaper.html\#letter1> (last accessed 17 July 2002).

138 Interview with Audrey Brown-Pereira, Acting High Commissioner for the Cook Islands (the author, Wellington, 6 August 2002). See also the First Report of the Constitutional Review Committee (Niue Constitutional Review Committee, December 2000) 14.

139 Interview with HE Hima Takelesi, High Commissioner for Niue (the author, Wellington, 31 July 2002).

140 See Ministry of Foreign Affairs and Trade <http://www.mfat.govt.nz/foreign/regions/pacific/ country/cookislandspaper.html $>$ (last accessed 17 July 2002); Ministry of Foreign Affairs and Trade $<$ http://www.mfat.govt.nz/foreign/regions/pacific/country/niuepaper.html> (last accessed 17 July 2002).

141 Cook Islands Constitution Act 1964 (NZ), s 5; Niue Constitution Act 1974 (NZ), s 6. 
Nothing in this Act or in the Constitution shall affect the responsibilities of Her Majesty the Queen in right of New Zealand for the external affairs and defence of the Cook Islands, those responsibilities to be discharged after consultation by the Prime Minister of New Zealand with the [Prime Minister] of the Cook Islands.

Nothing in this Act or in the Constitution shall affect the responsibilities of Her Majesty the Queen in right of New Zealand for the external affairs and defence of Niue.

The wording of these provisions does not reflect actual practice, which is that the assistance is provided by the New Zealand Government on the request and with the consent of the Governments of the Cook Islands and Niue. Nor, if the current arrangement were to be preserved, would the provisions reflect future practice, since it would be the Government of a republican New Zealand that would be providing the assistance, not Her Majesty the Queen in right of New Zealand. The current provisions would have to be replaced with something like this:

The Government of New Zealand shall have a continuing responsibility to assist in the external affairs and defence of [the Cook Islands or Niue, as appropriate] upon the request and with the consent of the Government of [the Cook Islands or Niue].

\section{Entrenchment}

The replacement of the defence and foreign affairs provisions with new ones to more accurately reflect future practice would be straightforward enough in New Zealand, since the Niue and Cook Islands Constitution Acts are ordinary, unentrenched Acts of Parliament, change to which would be unlikely to stimulate much political debate. But in the Cook Islands and Niue it would be more difficult. In both jurisdictions, any Bill repealing, amending, modifying, or extending the operative sections of the Constitution Act, or the provisions of the Constitution providing for the Head of State, requires two-thirds majority support in both the legislature and a referendum of voters. ${ }^{142}$ The other provisions of the Constitutions and Constitution Acts are not as deeply entrenched. Such a Bill must satisfy the same special majority requirement in the legislature, but otherwise only requires simple majority support in the referendum (in the case of Niue), and in the case of the Cook Islands, no referendum at all. ${ }^{143}$

To date, all constitutional amendments in both jurisdictions have been to shallowly-entrenched provisions. In practical terms, such changes are difficult enough - especially in the case of Niue, where all amendments require a referendum. Niue has only amended its Constitution once, in $1992 ;{ }^{144}$ the Cook Islands had amended its Constitution 22 times by mid-1997. But changes to the

142 Constitution of the Cook Islands, art 41(2); Constitution of Niue, art 35(1).

143 Constitution of the Cook Islands, art 41(1); Constitution of Niue, art 35(1).

144 Constitution Amendment (No 1) Act 1992 (Niue). 
deeply-entrenched provisions are another matter. None have been made to date in either jurisdiction, and change in the future could be almost impossible.

The defence and foreign affairs provisions sit at the heart of the free association relationships, and any change to them would be met with resistance. For a start, there would have to be broad support in the legislature. Opposition members would be likely to seize on the proposed changes as a Government plan to undermine the free association relationship. Then there would be the referendum, and voters would be likely to be put off supporting any change both by opposition scare-mongering and by the fact it would be the amendment Bill itself that they would have to vote on. ${ }^{145}$ A voting paper detailing a technical amendment to the constitution would be more likely to raise suspicion among voters than to receive their widespread support.

There is, however, legal authority in the Cook Islands that if followed could render a change to the defence and foreign affairs provisions less difficult than the entrenchment provisions in the Cook Islands and Niue Constitutions might suggest.

\section{Henry's case}

In 1981 the Cook Islands legislature enacted an amendment to the Constitution, which among other things provided that: ${ }^{146}$

[e]very reference to the Premier of the Cook Islands in any other law in force at the commencement of this Act [or] in any instrument or document of any kind whatsoever in force at the commencement of this Act shall, after the commencement of this Act, be read as a reference to the Prime Minister of the Cook Islands.

The adoption of 'Prime Minister' in place of 'Premier' was one of a number of changes in terminology apparently intended to remove any doubt as to the Cook Islands' powers of selfgovernment. Colonies have premiers; self-governing States have prime ministers. Niue's retention of the title 'Premier' for its chief Minister indicates the differing attitudes of the two countries.

The amendment Act was passed in accordance with the procedures for the amendment of shallowly-entrenched constitutional provisions set out in article 41(1) of the Constitution. But one of the laws in which a reference to the Premier was found was section 5 of the Cook Islands Constitution Act 1964 - the defence and foreign affairs provision.

An Opposition member of the Cook Islands legislature challenged the validity of the constitutional amendment in Henry $v$ Attorney-General. ${ }^{147}$ Henry contended that the purported

145 Constitution of the Cook Islands, art 41(2)(b); Constitution of Niue, art 35(1)(b).

146 Constitution Amendment (No 9) Act 1980-1981 (CI), s 18(2).

147 Henry v Attorney-General [1985] LRC (Const) 1149 (Cook Islands CA). Richardson J of the New Zealand Court of Appeal presided. 
change from 'Premier' to 'Prime Minister' involved an amendment or modification of section 5 of the Cook Islands Constitution Act 1964, a deeply-entrenched provision. ${ }^{148}$ Under article 41(2) of the Constitution, the amending Bill would have had to have been submitted to a referendum and have received at least two-thirds support. There had been no such referendum, so the amending Act was unconstitutional and void.

Henry originally commenced proceedings in the High Court of the Cook Islands, but the case was eventually removed into the Court of Appeal. The Court of Appeal held that the change from 'Premier' to 'Prime Minister' had been merely a change in nomenclature, and thus not an amendment, modification, or extension of section 5 of the Constitution Act, such as would have necessitated compliance with the special requirements for amendment of a deeply-entrenched provision. In the words of the Court, ${ }^{149}$

\footnotetext{
[the machinery for changing a deeply-entrenched provision] is called into operation only where ... it can fairly be said that what is involved is truly an amendment[,] modification or extension of section 5 . In the ordinary course a change of nomenclature alone cannot, we think, be characterised in that way so as to come within the amendment prescription in Article 41(2). To do so would require too legalistic and mechanical an approach to its construction.
}

Moreover, 150

[c]learly the substance of the section remains unchanged ... All that is affected is the label attaching to the Head of Government of the Cook Islands. The terms Premier and Prime Minister are in common use and on any fair reading they are synonymous for the purposes of section 5... [T] he pith and substance of section 5 , the true character of that provision, is not affected by the change in nomenclature.

Henry's application for relief was dismissed accordingly. ${ }^{151}$

With respect, the Court of Appeal's decision in Henry does not set the most principled of precedents. If judges who are accustomed to finding common-law solutions to problems of interpretation depart from the text of a written constitution in order to make it work in a particular case, they risk introducing uncertainty as to what the terms of the constitution actually are. Whatever the respective merits of written and unwritten constitutions, where the text of a written one purports to be exhaustive on a particular point, it should be accepted and reinforced by the Courts as the final word on the matter in question. An unstinting approach to human rights protections is one thing; to imply terms into a carefully-worded technical provision (whose purpose,

148 Henry, above, 1152-1153, Dillon J for the Court.

149 Henry, above.

150 Henry, above, 1154.

151 Henry, above. 
in this case, is to protect the integrity of the Constitution itself) is quite another, and one which undermines the written constitution as a catalogue of the fundamental rules of the polity.

In any case, was the change from 'Premier' to 'Prime Minister' really the mere change in terminology suggested by the Court of Appeal? After all, why would the Government have gone to the length of a constitutional amendment to make the change if it were not, in its eyes, one of substance?

Nevertheless, it may be that, given the difficulty of constitutional amendment, a pragmatic approach would be the only way of achieving the necessary changes to the defence and foreign affairs provisions in the Cook Islands and Niue Constitution Acts should New Zealand become a republic. The substance of those provisions as they currently stand is that the New Zealand Government provides defence and foreign affairs assistance to the Governments of the Cook Islands and Niue on their request and with their consent. If that substance stays the same, then a court seeking to achieve a sound practical result in the face of stringent entrenchment provisions may well be prepared to uphold an amendment that has not fully satisfied the requirements stipulated in the Constitution.

Alternatively, it may be possible to avoid the difficulties of constitutional amendment altogether, by re-stating the terms of the free association in a new form. When New Zealand and the Cook Islands set out to refresh the terms of the relationship in 2001, they chose to do it not by amending the Cook Islands Constitution Act, but instead by way of the Joint Centenary Declaration - a treaty of sorts. A document of this kind, perhaps a 'compact' such as that between the Marshall Islands and the United States of America, would be a suitable vehicle for the terms of the free association if the constitutional link between New Zealand and the Cook Islands and Niue were to come to an end.

It may well be that what is needed to get over the entrenchment hurdle is the momentum generated by change to the macroconstitutional arrangements of the Cook Islands and Niue. The necessity of that change and the different forms it might take are discussed in the following two parts of this paper.

\section{THE REALM LIVES ON, BUT NOT FOR LONG}

The change to a New Zealand republic would entail a wholesale revision of the New Zealand statute book. Changes would include the repeal of the Royal Titles Act 1974, the amendment of section 2 of the Constitution Act 1986 to allow for a president as Head of State, and the revocation of the Letters Patent.

But in Niuean and Cook Islands law, there would continue to be a Realm of New Zealand, implied in the Royal Titles Act (which is in force in both jurisdictions) and the Letters Patent 
(which, as a prerogative document, take effect as part of the law of the whole of the Realm). ${ }^{152}$ The Queen would continue to be the Head of State for the Cook Islands and Niue (under their respective Constitutions). Moreover, the Governor-General (who could have become New Zealand's first president) ${ }^{153}$ would continue as Her Majesty's representative in the Realm (under the Letters Patent), and would continue to have a role in relation to the Cook Islands and Niue under their respective Constitutions and other legislation.

On paper, the current macroconstitutional arrangements of the Cook Islands and Niue could continue. The Realm of New Zealand could survive New Zealand's becoming a republic. But for how long?

\section{A An Empty Executive Council}

One obstacle to the Realm's ongoing existence would be that the Governor-General and the Queen would be left without any advisers. New Zealand Members of Parliament, of whom the Executive Council is entirely composed, ${ }^{154}$ would no longer sit on the Executive Council. Since it is the Executive Council that advises the Queen and the Governor-General in the government of the Realm, ${ }^{155}$ no longer could either of them be advised (for example, in the use of the Seal of New Zealand).

Technically, the Governments of the Cook Islands and Niue could not advise Her Majesty to amend the Letters Patent to allow Cook Islands and Niuean Ministers to sit on the Executive Council, since the request would require an Order in Council, ${ }^{156}$ and there would effectively be no Council to make the Order.

\section{B A Redundant Governor-General}

Not only could the Governor-General of a Realm of New Zealand of which New Zealand was not a part not be advised; he or she would scarcely have anything to do. In the Cook Islands, the sole role would be to act as a channel for communications to the Queen, in conveying nominations for the position of Queen's Representative and for royal honours. The Queen's Representative otherwise

152 Alison Quentin-Baxter The Laws of New Zealand (Butterworths, Wellington, 2001) Pacific States and Territories: Cook Islands, para 15, 35 .

153 See Keith Locke MP Head of State Referenda Bill, cl 34.

154 Letters Patent Constituting the Office of Governor-General of New Zealand (SR 1983/225) cl VIII, as amended by the Letters Patent Amending Letters Patent constituting the Office of Governor-General of New Zealand (SR 1987/8).

155 Letters Patent Constituting the Office of Governor-General of New Zealand (SR 1983/225), cl VII.

156 See the Letters Patent of 31 December 1986 (SR 1987/8), preamble, for an illustration of this procedure. 
does everything in the Cook Islands the Governor-General does in New Zealand. ${ }^{157}$ And in Niue, once divested of the regulation-making power, the Governor-General would have only two functions besides the channelling of advice to the Queen. The first would be the appointment, swearing-in, and removal of judges, which is done on the direct advice of the Niue Cabinet, rather than via the Executive Council. ${ }^{158}$ The second would be the exercise of the prerogative of mercy, which, under the Letters Patent and the Niue Act 1966 (NZ), is the role of the Governor-General. ${ }^{159}$ By convention the Governor-General is advised by the responsible Minister, ${ }^{160}$ which in this case would be the Attorney-General of Niue.

\section{Obsolete Letters Patent}

If New Zealand left the Realm, the Letters Patent would become largely obsolete. They contain numerous references to New Zealand and New Zealand institutions, all of which would become redundant, ${ }^{161}$ and would need to be totally rewritten if they were to have any relevance to a Realm of New Zealand consisting of Niue and the Cook Islands alone.

\section{The Realm is Dead; Long Live Something Else}

If nothing were done in Cook Islands and Niue law when New Zealand became a republic, the Realm of New Zealand would grind to a halt. It would exist on paper but would not work in practice. One option at that point would be to make the technical legislative amendments required to keep the Realm alive and working. But change would inevitably go beyond a mere patch-up job.

A Realm of New Zealand minus New Zealand would be a distinctly unattractive option to all three States concerned. It makes some sense for the Realm to be called 'the Realm of New Zealand' now, since it grew out of the Dominion of New Zealand and New Zealand has historically been the dominant element within it. But if New Zealand were taken out, there would be no reason to preserve the name, and the Cook Islands and Niue would hardly want to keep it simply for historical reasons. Nor, presumably, would New Zealand want the name to continue if New Zealand were no longer part of the Realm.

157 Alison Quentin-Baxter The Laws of New Zealand (Butterworths, Wellington, 2001) Pacific States and Territories: Cook Islands, paras 11, 26.

158 Constitution of Niue, arts 42, 45, 52, 55C.

159 Letters Patent Constituting the Office of Governor-General of New Zealand (SR 1983/225) cl XI; Niue Act 1966 (NZ), s 286

160 Philip A Joseph Constitutional and Administrative Law in New Zealand (2 ed, Brookers, Wellington, 2001) 643.

161 Letters Patent Constituting the Office of Governor-General of New Zealand (SR 1983/225) cls I (reference to New Zealand as part of the Realm), VI (reference in the oath to be taken by the Governor-General to New Zealand as part of the Realm), XIX (Letters Patent as law of New Zealand). 
It is conceptually useful to think of New Zealand and the Realm as two separate things. But in reality, as the lopsided workings of the Realm reflect, the distinction is not an absolute one. Nor would it be enough of a distinction for the Realm to be able to live on if New Zealand were to secede from it. Despite what the structure set out in the Letters Patent might suggest, the Realm could not stand alone without New Zealand.

\section{FUTURE CONSTITUTIONAL OPTIONS}

If New Zealand became a republic, the Cook Islands and Niue would have a range of options open to them. The most likely ones would be self-governing realmhood and republichood in free association with New Zealand. But Niue could prefer to maintain its current constitutional link with New Zealand, or even to integrate with it.

\section{A Self-Governing Realmhood in Free Association with New Zealand}

Should the Cook Islands wish to keep the status quo in respect of their Head of State, it would not take much to turn it into the Realm of the Cook Islands. The main changes, aside from technical matters such as the appointment procedure, would be to rephrase article 2 of the Constitution so that it would refer to 'Her Majesty the Queen in right of the Cook Islands', and, if the standard pattern were to be followed, to issue new Letters Patent constituting the office of Governor-General of the Cook Islands and substitute 'Governor-General' for 'Queen's Representative' wherever it appears in the Constitution or other legislation.

Likewise, it would be relatively straightforward to turn Niue into a realm. Provision for a Governor-General could be made by way of new Letters Patent, and the references to the 'Queen in right of New Zealand' and the 'Governor-General of New Zealand' in article 1 of the Constitution and other legislation changed accordingly. As things stand, a Niuean Governor-General would have an extremely limited constitutional role, relating solely to the appointment of judges and the exercise of the prerogative of mercy. But rather than vesting those powers elsewhere and doing away with a local Queen's representative altogether, it could be desirable to have a GovernorGeneral to fulfil the social and ceremonial roles currently fulfilled by the Governor-General in New Zealand.

In 1996, when New Zealand implemented the New Zealand Order of Merit to replace certain British royal honours, the Cook Islands Government decided not to adopt the new order but instead to continue with the British honours it replaced, ${ }^{162}$ for the reason that the new order has a distinctly New Zealand flavour. ${ }^{163}$ This did not, however, deter Niue from adopting the new system, ${ }^{164}$

162 Alison Quentin-Baxter The Laws of New Zealand (Butterworths, Wellington, 2001) Pacific States and Territories: Cook Islands, para 27, 57.

163 Interview with Audrey Brown-Pereira, Acting High Commissioner for the Cook Islands (the author, Wellington, 6 August 2002). 
despite the fact that appointments are made on the recommendation of the Prime Minister of New Zealand, and the motto of the Order is in English and Maori (and none of the Realm's other languages), suggesting that if anything appointments to the Order are intended to reward services to New Zealand. ${ }^{165}$

It would be wrong to assume from the Cook Islands' retention of the British honours system that it has any particular desire to stick with the monarch. Rather, it was a case of not wanting to adopt the new New Zealand-focussed system, but instead retaining the status quo, which is wellrecognised and well-respected. ${ }^{166}$ Similarly, Niue's abandonment of the British honours should not be taken as a sign of opposition to the monarchy. The Queen is respected in both the Cook Islands and Niue. ${ }^{167}$ The question of whether they would become separate realms upon New Zealand's becoming a republic would ultimately depend on whether there were enough enthusiasm for the Sovereign to want to keep her.

\section{B Self-Governing Republichood in Free Association with New Zealand}

There is a republican alternative to self-governing realmhood in free association with New Zealand. If the Cook Islands and Niue wished to become republics like New Zealand, then, assuming a ceremonial rather than executive president is desired, the practical steps would be more or less identical in form to those required for them to become realms. Given their long and intimate links with New Zealand, Niue and the Cook Islands tend to take their lead from New Zealand in constitutional matters. It is possible that republican momentum in New Zealand may flow on to the islands.

\section{A Modified Status Quo}

A third option, unlikely for the Cook Islands but a possibility for Niue, is the adoption of a similar constitutional relationship to the current one. If Niue were to retain New Zealand's Head of State, the changes required in Niue law would be relatively few. Article 1 of the Niue Constitution would be the main provision in need of amendment.

The question of whether the link could continue, and if so in what form, would be a crucial one for both parties. New Zealand would need to be sensitive to Niue's fragile situation, and Niue would need to respect New Zealand's desire to get to grips with its own constitutional arrangements. It may

164 Interview with HE Hima Takelesi, High Commissioner for Niue (the author, Wellington, 31 July 2002).

165 See Statutes of the New Zealand Order of Merit (SR 1996/205), cls 13, 21.

166 Interview with Audrey Brown-Pereira, Acting High Commissioner for the Cook Islands (the author, Wellington, 6 August 2002).

167 Interview with Audrey Brown-Pereira, Acting High Commissioner for the Cook Islands (the author, Wellington, 6 August 2002); interview with HE Hima Takelesi, High Commissioner for Niue (the author, Wellington, 31 July 2002). 
be, for example, that Niue could not expect to have much of a say in the appointment or election of the president. On the basis of Niue's approximately 2,000 local residents and New Zealand's population of around four million, Niue would be entitled to one two-thousandth of a say. Clearly, something more than that would be required. But the right to elect or appoint every second president would be taking things too far. Some kind of mutually-acceptable selection process would have to be agreed upon.

On the other hand, as things currently stand Niue has no say in the appointment of the Governor-General. If it were to continue to get its Head of State for free, perhaps under a borrowing arrangement rather than a sharing one, and if this were acceptable to New Zealand, it would not be crucial for the Niue Government or Niueans to have a say in the selection of the president.

\section{Integration with New Zealand}

The fourth option, integration with New Zealand, is probably well off the cards for the Cook Islands, which wants to be seen internationally as a sovereign and independent State in free association with New Zealand. ${ }^{168}$ With its 14,000 local residents and relatively high GDP per capita per annum $\left(\$ 11,000\right.$ in 2000), ${ }^{169}$ the Cook Islands makes a small but not unviable self-governing state.

Niue, on the other hand, is in a much more precarious position. The local population is fewer than 2,000, and GDP per capita $\$ 8750$ per annum. ${ }^{170}$ The fragile economy is heavily dependent on New Zealand budgetary support, which constitutes almost one fifth of Niue's annual income. ${ }^{171}$ It is not surprising, therefore, that when in 2000 the Constitutional Review Committee sought the views of 871 Niuean voters on the three options of self-government in free association with New Zealand, integration with New Zealand, and independence, 22 per cent were in favour of integration (with self-government in free association with New Zealand and independence attracting 66 per cent and 7 per cent support respectively). ${ }^{172}$ Whereas Chatham Islanders have in the past looked enviously at

168 Interview with Audrey Brown-Pereira, Acting High Commissioner for the Cook Islands (the author, Wellington, 6 August 2002). See also the Joint Centenary Declaration of the Principles of the Relationship Between New Zealand and the Cook Islands (11 June 2001) cl 4(1)

169 Ministry of Foreign Affairs and Trade <http://www.mfat.govt.nz/foreign/regions/pacific/country/cook islandspaper.html $>$ (last accessed 17 July 2002).

170 Ministry of Foreign Affairs and Trade <http:/www.mfat.govt.nz/foreign/regions/pacific/country/ niuepaper.html $>$ (last accessed 17 July 2002).

171 Ministry of Foreign Affairs and Trade <http:/www.mfat.govt.nz/foreign/regions/pacific/country/ niuepaper.html $>$ (last accessed 17 July 2002).

172 First Report of the Constitutional Review Committee (Niue Constitutional Review Committee, December 2000) 16 . 
self-governing Niue, ${ }^{173}$ a reasonable proportion of Niueans would prefer a closer constitutional arrangement with New Zealand than they have at present.

It has been assumed in this paper that Niue would wish to preserve its current status of selfgovernment in free association with New Zealand. It may, however, be that Niue's future security will be better achieved through full integration. Such a change would presumably involve harmonising governmental structures in Niue with New Zealand's system of local government, and creating a Niuean constituency for electoral purposes. Integration would be considerably more complex than any of the other options presented here.

\section{CONCLUSION}

It seems highly likely that at some future point New Zealand will become a republic. If the Prime Minister's predictions are correct, and New Zealand does abolish its current Head of State, its doing so will not necessarily undermine the continued existence of relationships of free association between and the Cook Islands and Niue. But it will bring about the death of the Realm of New Zealand. Constitutional change in New Zealand will breed constitutional change in the islands.

The form of that change in Niue and the Cook Islands will be for them to choose. Total constitutional independence from New Zealand under some kind of freely-associated monarchical or republican status is the most likely outcome, and may well be viewed by the Cook Islands as a way of partially alleviating its frustration at not being seen internationally as an independent state. Niue may not be so keen to sever the constitutional link with New Zealand, and if that is the case will have the difficult task of negotiating with New Zealand the terms of its constitutional future.

New Zealand will have an important role to play in helping Niue and the Cook Islands to make whatever changes to their Constitutions they feel are most appropriate. It has already promised as much to the Cook Islands in the Joint Centenary Declaration: ${ }^{174}$

In all matters affecting the Realm of New Zealand, of which the Cook Islands and New Zealand are part,

there will be close consultation between the signatories.

The importance of close consultation was also alluded to by the Governor-General at Niue's centenary celebrations in October 2001. In her address Dame Silvia spoke of the need for the two countries to "continue to work together to ensure that a way forward is found". ${ }^{175}$

173 First Report of the Constitutional Review Committee, above, 49.

174 Joint Centenary Declaration of the Principles of the Relationship Between New Zealand and the Cook Islands (11 June 2001), cl 3(2).

175 HE Hon Dame Silvia Cartwright PCNZM DBE, Governor-General of New Zealand (Speech at the celebrations marking the centenary of formal ties between New Zealand and Niue, Alofi, 19 October 2001). 
It is all very well for New Zealand to head off down the republican track, but there is more to this Realm than New Zealand alone. New Zealand's republican agenda must consider the Cook Islands and Niue. They cannot be left in the constitutional lurch. 
